\title{
Interleukin-6 and the IL-6 (-174) C/G polymorphism in breast pathologies and in HIV-infected patients
}

Elżbieta Jabłonowska ${ }^{1}$, Agnieszka Kołacinska², Jan Kuydowicz'1 Karolina Przybyłowska³, Zbigniew Jabłonowski ${ }^{4}$

1Department of Infectious Diseases and Hepatology, Medical University of Lodz, Poland 2Department of Surgical Oncology, Copernicus Memorial Hospital, Lodz, Poland 3Department of General and Colorectal Surgery, Medical University of Lodz, Poland ${ }_{4}^{4} 1^{\text {st }}$ Department of Urology, Medical University of Lodz, Poland

Submitted: 254 October 2009

Accepted: 23 December 2009

Arch Med Sci 2010; 6, 6: 860-865

DOI: 10.5114/aoms.2010.19292

Copyright @ 2010 Termedia \& Banach

\section{Abstract}

Introduction: Breast cancer and acquired immunodeficiency syndrome (AIDS) are key issues for modern medicine. The aim of the current study was to present how cytokines, in the example of IL- 6 and its polymorphism, can affect these two conditions.

Material and methods: Thirty-one women with benign breast tumours, 42 breast cancer patients and $40 \mathrm{HIV}$-infected females were enrolled in the study. Serum IL- 6 levels were determined by ELISA. The IL- 6 polymorphism was genotyped by PCR-RFLP.

Results: Serum IL- 6 in patients with benign breast tumours was significantly lower than in females with breast cancer $(p=0.017)$ and HIV-infected women $(p=0.032)$. We did not find statistically significant differences in serum IL-6 level between females with breast cancer and HIV-infected women $(p=0.749)$. Comparing the distribution of genotypes and frequency of the IL-6 (-174) C/G polymorphism between the three study groups - breast cancer patients, patients with benign breast tumours, and HIV-infected patients - we did not find any statistically significant differences.

Conclusions: IL- 6 can play an important role in pathogenesis of breast cancer and HIV infection and its level is higher than in the control group irrespective of distribution of genotypes and frequency of the IL-6 (-174) C/G polymorphism.

Key words: interleukin-6, polymorphism, breast diseases, HIV

\section{Introduction}

Most research shows that breast cancer occurs less frequently in women infected with HIV than in those not infected [1-5]. Several hypotheses have been proposed to try to explain this tendency. It could be caused by the direct suppressive effect the virus has on the proliferation of breast cancer cells, or by its effect on the functioning of the immune system.

Not all authors agree on this matter. Pathologists in India [6] have observed that breast cancer is the most common AIDS unrelated cancer which occurs in HIV-infected women. Furthermore, they have shown, in their research, that women in whom both HIV infection and breast cancer

\author{
Corresponding author: \\ Zbigniew Jabłonowski, MD, \\ $\mathrm{PhD}$ \\ I Department of Urology \\ Medical University of Lodz \\ Żeromskiego 113 \\ 90-549 Lodz, Poland \\ Phone: +48 661116860 \\ Fax: +48 422516180 \\ E-mail: zby_szek@tlen.pl
}


were diagnosed had a worse prognosis than those who had not been infected.

Recent data suggest that chemokines might not only be the main protagonists in breast cancerogenesis but could also play an essential role in the pathogenesis of HIV. IL-6 possibly plays an important role, as a pro-inflammatory chemokine, in both of these processes. The role of IL- 6 in carcinogenesis in patients with chronic viral infection such as HIV infection is truly interesting. Lee et al. demonstrated that HIV-1 Tat protein, actively released from HIV-infected cells, upregulates expression of $\mathrm{IL}-6$ and $\mathrm{IL}-8$ in human breast cancer cells by an NF-кB-dependent pathway [7]. Moreover, IL-6 concentration is dependent on many environmental and genetic factors, which determine individual differences in the production of this cytokine. One of these factors is the $-174 \mathrm{C} / \mathrm{G}$ polymorphism, which is found in the promoter region of the IL- 6 gene. The presence of the $\mathrm{G} / \mathrm{G}$ allele is connected with higher concentrations of IL- 6 and is seen most frequently. Other polymorphic forms such as C/C or G/C alleles are associated with lower levels of IL-6.

The aim of the study was to assess serum IL- 6 levels and $-174 \mathrm{G} / \mathrm{C}$ polymorphism in the promoter region of the IL- 6 gene in three groups of patients: females with benign breast tumours, breast cancer patients, and HIV-infected women.

\section{Material and methods}

Between January and September 2007, 31 women with benign breast disease, 42 breast cancer patients, and 40 HIV-infected females treated respectively in the Department and Outpatient Department of Surgical Oncology, Copernicus Memorial Hospital, and the Outpatient Department of Acquired Immunodeficiencies, Medical University of Lodz, were recruited into the study after ethical approval from the Medical University of Lodz. Following written informed consent, blood samples were collected, from surgically treated women preoperatively. All breast disease was diagnosed by means of clinical examination, ultrasonography, mammography, fine needle aspiration or core biopsy and histopathological examination in those patients operated upon.

The mean age of women with benign breast lesions, who formed the control group, was 36.03 years (range 19-68 years). The mean tumour diameter was $31.3 \mathrm{~mm}$ (range 7-80 mm). This cohort included 22 patients with fibroadenomas, 4 women with mammary cysts and 5 adenolipomas. No signs of inflammation or cancer were present. No history of concomitant diseases was reported.

The age of breast cancer patients ranged between 30 and 64 years (mean 37.69 years). This cohort included 2 cases of ductal carcinoma in situ, 33 cases of invasive ductal carcinoma and 7 lobular cancers. The mean tumour diameter was $29.57 \mathrm{~mm}$ (range 4-100 mm). Twenty-two females were oestrogen receptor (ER) positive, 18 were progesterone receptor (PR) positive, and 10 were HER-2 positive. In 16 subjects positive axillary lymph nodes were present. No distant metastases were detected. Nine cancer patients received neoadjuvant chemotherapy.

The mean age of HIV-infected women was 34.75 years (range 22-65 years). CD 4 T cell count ranged between 34 and 2006 cells/ $\mu$ l (mean 438.05). Viraemia was under 40 copies/ml in 14 subjects. In 26 HIV-infected patients viraemia ranged between 52 and 222000 copies/ml, mean 22566.2 copies/ml. Twenty-three females out of 40 HIV-infected individuals were treated with antiretroviral agents. In 4 HIV-infected patients benign breast lesions (3 lipomas and 1 benign mammary dysplasia) were diagnosed by means of clinical examination, ultrasonography, mammography and fine needle aspiration. No breast cancers were found in this group of patients. Serum IL-6 levels were determined by sandwichtype enzyme-linked immunosorbent assay (ELISA) according to the manufacturer's protocol: PelikineCompact human IL-6 ELISA kit (Sanquin Reagents, Amsterdam, The Netherlands) for the quantification of IL-6. The absorbance was read at $450 \mathrm{~nm}$.

The IL-6 polymorphism was genotyped by polymerase chain reaction-restriction fragment length polymorphism (PCR-RFLP). Primer sequences for PCR were as follows: 5'-TGACTTCAGCTTTACTCTTTGT-3', 5'-CTGATTGGAAACCTTATTAAG-3'. PCR was carried out in a volume of $25 \mu \mathrm{l}$ containing $1.5 \mathrm{mmol} / \mathrm{l}$ $\mathrm{MgCl}_{2}, 0.2 \mathrm{mmol} / \mathrm{l}$ of each deoxynucleotide triphosphates, $0.2 \mathrm{mmol} / / \mathrm{l}$ of each primer (Eurogentec, Darmstad, Belgium) and 2.5 units of Taq polymerase (Qiagen $\mathrm{GmbH}$, Hilden, Germany). The DNA was amplified during 35 cycles with an initial denaturation at $94^{\circ} \mathrm{C}$ for $10 \mathrm{~min}$, and final extension at $72^{\circ} \mathrm{C}$ for $10 \mathrm{~min}$. The cycle programme consisted of $1 \mathrm{~min}$ denaturation at $94^{\circ} \mathrm{C}, 1 \mathrm{~min}$ and $35 \mathrm{~S}$ annealing at $55^{\circ} \mathrm{C}$, and $1 \mathrm{~min}$ extension at $72^{\circ} \mathrm{C}$. PCR products were digested with $S f$ aNI restriction enzyme at $37^{\circ} \mathrm{C}$ overnight and electrophoresed on a $2 \%$ agarose gel. $S f$ aNI restriction fragment-length polymorphism (RFLP) was detected by ethidium bromide staining. PCR was used to detect the IL-6 S $f$ aNI RFLP. The identified genotypes were named according to the presence or absence of the enzyme restriction sites, so $S \mathrm{f} a \mathrm{NI} \mathrm{G/G}, \mathrm{G} / \mathrm{C}$, and $\mathrm{C} / \mathrm{C}$ are homozygous for the presence of the site (140/58 bp), heterozygous for the presence and absence of the site 
(198/140/58 bp), and homozygous for the absence of the site (198 bp), respectively.

Probability $(p)$ value $<0.05$ was considered statistically significant. The $t$-test (for normal distribution) or Mann-Whitney test (for non-normal distribution) was used to compare each variable between two groups. An ANOVA test was used to identify variables showing significant differences between more than two groups; Scheffe's test was then used to test the significance of difference in each identified variable between any two groups.

Analyses were performed using STATISTICA 6.0 (StatSoft, Tulsa, OK).

\section{Results}

The mean age of women with benign breast lesions was 37.03 years (range 19-68 years). The mean tumour diameter was $31.3 \mathrm{~mm}$ (range 7-80 mm). The age of breast cancer patients ranged between 30 and 64 years (mean 38.69 years). This cohort included 2 cases of ductal carcinoma in situ, 33 cases of invasive ductal carcinoma, and 7 patients with lobular cancer. The mean tumour diameter was $29.57 \mathrm{~mm}$ (range 4-100 mm). Twentytwo females were ER positive, 18 were PR positive, and 10 were HER-2 positive. Nine cancer patients received neoadjuvant chemotherapy. The mean age of HIV-infected women was 34.75 years (range 2265 years). CD 4 count ranged between 34 and 2006 cells/ $\mu$ l (mean 438.05). Viraemia was below 40 copies/ml in 14 subjects. In 26 HIV-infected patients, viraemia ranged between 52 and 222000 copies/ml (mean 22566.2 copies/ml). Twenty-three females of $40 \mathrm{HIV}$-infected individuals were treated with antiretroviral agents. In 4 HIV-infected patients benign breast lesions were diagnosed by means of clinical examination, ultrasonography, mammography and fine needle aspiration. No breast cancers were found in the aforementioned group.

In women with benign breast tumours the level of IL- 6 ranged between 0 and $110.25 \mathrm{pg} / \mathrm{ml}$, mean $20.24 \mathrm{pg} / \mathrm{ml}$, in breast cancer patients between 0 and $153.44 \mathrm{pg} / \mathrm{ml}$, mean $25.17 \mathrm{pg} / \mathrm{ml}$, and in HIV-infected females between 10.09 and 216.50 $\mathrm{pg} / \mathrm{ml}$, mean $47.36 \mathrm{pg} / \mathrm{ml}$, respectively (Table I).

Serum IL-6 levels (in pg/ml) in the three study groups are shown in Table I. Serum IL-6 in patients with benign breast tumours was significantly lower than in females with breast cancer $(p=0.017)$ and HIV-infected women $(p=0.032)$. We did not find statistically significant differences in serum IL-6 level between females with breast cancer and HIVinfected women ( $p=0.749$ ). Serum IL-6 levels depending on genotypes in patients with benign breast tumours, breast cancer and HIV are presented in Tables II-IV, respectively.

The frequency of $\mathrm{G} / \mathrm{G}$ genotype in breast cancer patients, HIV-infected subjects and women with benign breast lesions was $0.54,0.59$ and 0.59 ,

Table I. Serum IL-6 levels (in pg/ml) in patients with benign breast tumours, breast cancer and HIV

\begin{tabular}{|lccc|}
\hline & Benign breast tumours, $N=31$ & Breast cancer, $N=42$ & HIV, $N=40$ \\
\hline Mean & 20.24 & 25.17 & 47.36 \\
\hline SD & 17.94 & 21.67 & 61.32 \\
\hline SEM & 3.22 & 3.34 & 9.69 \\
\hline Median (25\%; 75\%) & $18.16(12.88 ; 22.55)$ & $21.73(17.51 ; 25.76)$ & $21.27(15.17 ; 36.72)$ \\
\hline Min & 0.00 & 0.00 & 10.09 \\
\hline Max & 110.25 & 153.44 & 216.50 \\
\hline
\end{tabular}

Table II. Serum IL-6 levels $(\mathrm{pg} / \mathrm{ml})$ depending on genotypes in patients with benign breast tumours. Statistical analysis

\begin{tabular}{|c|c|c|c|c|c|c|}
\hline Genotype & Mean & SD & Min & Max & Median (25\%; 75\%) & Statistical analysis \\
\hline $\mathrm{G} / \mathrm{G}$ & 16.64 & 5.67 & 6.30 & 25.44 & $16.91(12.39 ; 21.47)$ & $\mathrm{G} / \mathrm{G}$ vs. $\mathrm{G} / \mathrm{C} p=0.366$ \\
\hline $\mathrm{G} / \mathrm{C}$ & 25.72 & 29.04 & 0.00 & 110.53 & $19.71(13.52 ; 23.60)$ & \\
\hline $\mathrm{C} / \mathrm{C}$ & - & - & - & - & - & \\
\hline
\end{tabular}

Table III. Serum IL-6 levels (pg/ml) depending on genotypes in breast cancer patients. Statistical analysis

\begin{tabular}{|c|c|c|c|c|c|c|}
\hline Genotype & Mean & SD & Min & Max & Median (25\%; $75 \%)$ & Statistical analysis \\
\hline $\mathrm{G} / \mathrm{G}$ & 26.37 & 29.15 & 0.00 & 153.44 & $20.90(15.87 ; 27.07)$ & $\mathrm{G} / \mathrm{G}$ vs. $\mathrm{G} / \mathrm{C} p=0.488$ \\
\hline $\mathrm{G} / \mathrm{C}$ & 24.35 & 8.65 & 11.29 & 46.62 & $23.15(18.08 ; 25.60)$ & \\
\hline $\mathrm{C} / \mathrm{C}$ & 15.86 & - & 15.86 & 15.86 & 15.86 (----; ----) & \\
\hline
\end{tabular}


Table IV. Serum IL-6 levels $(\mathrm{pg} / \mathrm{ml})$ depending on genotypes in HIV-infected patients. Statistical analysis

\begin{tabular}{|c|c|c|c|c|c|c|}
\hline Genotype & Mean & SD & Min & Max & Median (25\%; 75\%) & Statistical analysis \\
\hline $\mathrm{G} / \mathrm{G}$ & 47.31 & 64.34 & 10.96 & 216.51 & $19.63(13.74 ; 39.67)$ & G/G vs. G/C $p=0.310$ \\
\hline $\mathrm{G} / \mathrm{C}$ & 49.85 & 62.56 & 11.53 & 205.14 & $24.46(18.99 ; 29.58)$ & \\
\hline $\mathrm{C} / \mathrm{C}$ & 34.76 & - & 34.76 & 34.76 & 34.76 & \\
\hline
\end{tabular}

respectively (Tables V-VII). The frequency of $\mathrm{G} / \mathrm{C}$ and $\mathrm{C} / \mathrm{C}$ genotypes are presented in Tables V-VII.

\section{Discussion}

Numerous controversies have arisen over the role of IL 6 in breast cancer development. Some researchers emphasize the protective role this cytokine has on the development of this tumour. They point out its suppressive effect on the growth of diverse cell lines associated with breast cancer development as well as its anti-adhesive properties [8-10]. Moreover, this cytokine plays an essential role in the regulation of processes associated with the production of oestrogens, through its effect on such enzymes as aromatase and steroid sulfatase, also called $17 \beta$-hydroxysteroid dehydrogenase, which may have an effect on the risk of developing breast cancer. A raised concentration of IL 6 was observed to be an independent, favourable prognostic factor in the course of breast cancer

Table V. Distribution of genotype and frequency of IL-6 (-174) G/C polymorphism in breast cancer patients and benign breast tumours

\begin{tabular}{|lccc|}
\hline $\begin{array}{l}\text { Genotype } \\
\text { Allele }\end{array}$ & $\begin{array}{c}\text { Breast cancer patients }(n=41) \\
\text { Number (Frequency) }\end{array}$ & $\begin{array}{c}\text { Benign breast tumours }(n=30)^{\mathrm{a}} \\
\text { Number (Frequency) }\end{array}$ & $\begin{array}{c}\text { Odds Ratio } \\
(95 \% \mathrm{Cl})\end{array}$ \\
\hline $\mathrm{G} / \mathrm{G}$ & $22(0.54)$ & $19(0.63)$ & $0.67(0.25 ; 1.76)$ \\
\hline $\mathrm{G} / \mathrm{C}$ & $18(0.44)$ & $11(0.37)$ & $1.35(0.51 ; 3.55)$ \\
\hline C/C & $1(0.02)$ & $0(0.00)$ & - \\
\hline G & $62(0.76)$ & $49(0.82)$ & $0.69(0.30 ; 1.59)$ \\
\hline C & $20(0.24)$ & $11(0.18)$ & $1.43(0.63 ; 3.28)$ \\
\hline
\end{tabular}

$a_{p}>0.05$ distribution consistent with Hardy-Weinberg equilibrium

Table VI. Distribution of genotype and frequency of IL-6 (-174) G/C polymorphism in HIV-infected patients and benign breast tumours

\begin{tabular}{|lccc|}
\hline $\begin{array}{l}\text { Genotype } \\
\text { Allele }\end{array}$ & $\begin{array}{c}\text { HIV-infected patients }(n=39) \\
\text { Number (frequency) }\end{array}$ & $\begin{array}{c}\text { Benign breast tumours }(n=30)^{\mathrm{a}} \\
\text { Number (frequency) }\end{array}$ & $\begin{array}{c}\text { Odds ratio } \\
(95 \% \mathrm{Cl})\end{array}$ \\
\hline $\mathrm{G} / \mathrm{G}$ & $23(0.59)$ & $19(0.63)$ & $0.83(0.31 ; 2.21)$ \\
\hline $\mathrm{G} / \mathrm{C}$ & $15(0.38)$ & $11(0.37)$ & $1.08(0.40 ; 2.88)$ \\
\hline $\mathrm{C} / \mathrm{C}$ & $1(0.03)$ & $0(0.00)$ & - \\
\hline G & $61(0.78)$ & $49(0.82)$ & $0.81(0.34 ; 1.87)$ \\
\hline C & $17(0.22)$ & $11(0.18)$ & $1.24(0.53 ; 2.89)$ \\
\hline
\end{tabular}

$a_{p}>0.05$ distribution consistent with Hardy-Weinberg equilibrium

Table VII. Distribution of genotype and frequency of the IL-6 (-174) G/C polymorphism in HIV-infected patients and breast cancer patients

\begin{tabular}{|lcc|}
\hline Genotype Allele & $\begin{array}{c}\text { HIV-infected patients }(n=39) \\
\text { Number (frequency) }\end{array}$ & $\begin{array}{c}\text { Breast cancer patients }(n=41) \\
\text { Number (frequency) }\end{array}$ \\
\hline G/G & $23(0.59)$ & $22(0.54)$ \\
\hline G/C & $15(0.38)$ & $18(0.44)$ \\
\hline C/C & $1(0.03)$ & $1(0.02)$ \\
\hline G & $61(0.78)$ & $62(0.76)$ \\
\hline C & $17(0.22)$ & $20(0.24)$ \\
\hline
\end{tabular}

$p>0.05$ distribution in HIV-infected patients consistent with distribution in breast cancer patients 
$[11,12]$. Contrary to the above-cited studies, other researchers have found that women with breast cancer had a higher concentration of this interleukin in comparison with healthy women. They also stated that these women had a worse prognosis [13].

Thanks to the development of molecular genetics, changes in single nucleotides in polymorphic fragments of coding genes which are responsible for the production of this interleukin have been discovered. It has been found that the presence of different allelic forms in these fragments is connected with different affinities towards transcription factors which in effect contribute to diverse protein expression. The G/G allele is connected with higher concentrations of IL- 6 and is seen most frequently. Other polymorphic forms such as $\mathrm{C} / \mathrm{C}$ or $\mathrm{G} / \mathrm{C}$ alleles are associated with lower levels of IL-6.

Knowing that IL- 6 plays an important role in the process of carcinogenesis, many researchers have started to try to establish the significance of polymorphic changes in the 174 position to determine the risk of breast cancer development as well as the risk of progression of this disease. The results of many publications pertaining to this topic are contradictory.

Hefler et al. (14) stated that the IL-6 gene G-174C increases the risk of breast cancer development. Other researchers, on the other hand, have not published statistically significant results comparing the prevalence of certain alleles in women with breast cancer in comparison with their prevalence in healthy women [1, 10, 12, 15-17]. DeMichele et al. [16] believe that G-174C IL-6 polymorphism is a better prognostic factor in patients with high risk breast cancer. However, lacopetta et al. [18] stated that the occurrence of polymorphism is a prognostic factor pointing toward a more aggressive course of breast cancer progression. Other researchers found there to be no connection between IL- 6 gene 174 polymorphism and the clinical or histopathological outcome of breast cancer $[15,14,18]$.

In the presented research we found there to be a statistically significantly higher level of IL-6 in the group of patients with breast cancer compared to the group with benign breast tumours. We did not perform subgroup analysis of cytokine concentrations in the breast cancer cohort in relation to staging, due to the small numbers of patients, but positive axillary lymph nodes were detected in 16 out of 42 females. In our study the $\mathrm{G} / \mathrm{G}$ allele, which genetically predisposes to a higher production of IL-6, was not significantly more frequent in patients with breast cancer in comparison with the group of patients with benign breast tumours. A similar situation was seen in patients infected with HIV. Higher concentrations, in both the group of women with breast cancer and that with HIV compared to the studied group of women with benign breast lesions, were not associated with IL-6 gene 174 polymorphism. Therefore the observed higher concentrations of IL 6 in the groups infected with HIV and in women with breast cancer were not associated with the genetic determinants which we studied.

The observation made by American researchers in which they stated that HIV-1 Tat protein increases the potential of human cell cultures to form metastases through the up-regulation of both IL-6 and IL- 8 as well as mRNA matrix metalloproteinase MMP-9 [7] seems interesting. However, in the group of HIV patients which we studied, we did not have any cases of breast cancer; therefore it is hard to relate to this observation.

IL-6 can play an important role in the pathogenesis of breast cancer and HIV infection, and its level is higher than in the control group irrespective of the distribution of genotypes and frequency of the IL-6 (-174) C/G polymorphism.

\section{Acknowledgments}

Supported by internal grant Medical University of Lodz 502-11-724.

\section{References}

1. Goedert JJ, Schairer C, McNeel TS, Hessol NA, Rabkin CS, Engels EA; HIV/AIDS Cancer Match Study. Risk of breast, ovary, and uterine corpus cancers among 85,268 women with AIDS. Br J Cancer 2006; 95: 642-8.

2. Head JF, Elliott RL, McCoy JL. Evaluation of lymphocyte immunity in breast cancer patients. Breast Cancer Res Treat 1993; 26: 77-88.

3. Intra M, Gentilini O, Brenelli F, Chagas EM, Veronesi U, Sandri MT. Breast cancer among HIV-infected patients: the experience of the European Institute of Oncology. J Surg Oncol 2005; 91: 141-2.

4. Pantanowitz L, Dezube BJ. Breast cancer in women with HIV/AIDS. JAMA 2001; 285: 3090-1.

5. Pantanowitz L. Breast cancer and AIDS. J Natl Med Assoc 2001; 93: 40-1.

6. Anshu, Shivkumar VB, Gangane N, Sharma S. Metaplastic carcinoma of the breast in an HIV-positive patient: a case report. Acta Cytol 2005; 49: 204-6.

7. Lee YW, Hirani AA, Kyprianou N, Toborek M. Human immunodeficiency virus-1 Tat protein up-regulates interleukin-6 and interleukin-8 expression in human breast cancer cells. Inflamm Res 2005; 54: 380-9.

8. Asgeirsson KS, Olafsdottir K, Jonasson JG, Ogmundsdottir HM. The effects of IL-6 on cell adhesion and e-cadherin expression in breast cancer. Cytokine 1998; 10: 720-8.

9. Badache A, Hynes NE. Interleukin 6 inhibits proliferation and, in cooperation with an epidermal growth factor receptor autocrine loop, increases migration of T47D breast cancer cells. Cancer Res 2001; 61: 383-91.

10. Danforth DN Jr, Sgagias MK. Interleukin-1 $\alpha$ and interleukin-6 act additively to inhibit growth of MCF-7 breast cancer cells in vitro. Cancer Res 1993; 53: 1538-45. 
11. Bachelot T, Ray-Coquard I, Menetrier-Caux C, Rastkha M, Duc A, Blay JY. Prognostic value of serum levels of interleukin 6 and of serum and plasma levels of vascular endothelial growth factor in hormone-refractory metastatic breast cancer patients. Br J Cancer 2003; 88: 1721-6.

12. Bozcuk H, Uslu G, Samur M, et al. Tumour necrosis factor, interleukin-6, and fasting serum insulin correlate with clinical outcome in metastatic breast cancer patients treated with chemotherapy. Cytokine 2004; 27: 58-65.

13. Zhang GJ, Adachi I. Serum interleukin-6 levels correlate to tumor progression and prognosis in metastatic breast carcinoma. Anticancer Res 1999; 19: 1427-32.

14. Hefler LA, Grimm C, Lantzsch T, et al. Interleukin-1 and interleukin- 6 gene polymorphisms and the risk of breast cancer in caucasian women. Clin Cancer Res 2005, 11: 5718-21.

15. Balasubramanian SP, Azmy IA, Higham SE, et al. Interleukin gene polymorphisms and breast cancer: a case control study and systematic literature review. BMC Cancer 2006; 6: 188.

16. DeMichele A, Martin AM, Mick R, et al. Interleukin-6 -174 GC polymorphism is associated with improved outcome in high-risk breast cancer. Cancer Res 2003; 63: 8051-6.

17. González-Zuloeta Ladd AM, Arias Vásquez A, et al. Interleukin 6 G-174 C polymorphism and breast cancer risk. Eur J Epidemiol 2006; 21: 373-6.

18. lacopetta B, Grieu F, Joseph D. The -174 G/C gene polymorphism in interleukin- 6 is associated with an aggressive breast cancer phenotype. Br J Cancer 2004; 90: 419-22.

19. Przybylowska K, Kluczna A, Zadrozny $M$, et al. Polymorphisms of the promoter regions of matrix metalloproteinases genes MMP-1 and MMP-9 in breast cancer. Breast Cancer Res Treat 2006; 95: 65-72. 